\title{
Investigation of Country Bias in International Genetic Evaluations Using Full-Brother Information
}

\author{
R. L. Powell, ${ }^{1}$ A. H. Sanders, ${ }^{2}$ and H. D. Norman \\ Animal Improvement Programs Laboratory, Agricultural Research Service, USDA, Beltsville, MD 20705-2350
}

\begin{abstract}
International Bull Evaluation Service evaluations from May 2005 were examined for country bias by comparing Holstein full-brother families. Countries with $\geq 25$ bulls in multicountry full-brother families were included. The model fit evaluations of US estimated breeding values (EBV) by absorbing full-brother family and producing solutions for country of brothers. For yield and somatic cell score, 24,611 and 22,802 bulls, respectively, were included in the analysis. The study was repeated fitting evaluations on the scales of 9 countries other than the United States. On all countries' scales, bulls from Australia, Germany, Great Britain, and Japan had greater EBV for milk yield than did their full brothers from the United States; Italian bulls had lower EBV. Bulls from Australia, Great Britain, and South Africa had an advantage in EBV for fat yield. For EBV for protein yield, bulls from Germany, Great Britain, Japan, and South Africa had an advantage, whereas bulls from the Netherlands were disadvantaged. For somatic cell score, US bulls were advantaged compared with bulls from South Africa. Significance and rankings of apparent biases were similar across country scales of the international evaluations. Causes of those differences are unknown; differences in incorporation of parental data in national and International Bull Evaluation Service evaluations are a possibility.

Key words: genetic evaluation, International Bull Evaluation Service, genetic correlation
\end{abstract}

\section{INTRODUCTION}

The International Bull Evaluation Service (Interbull, Uppsala, Sweden) provides international genetic evaluation for AI-sampled bulls with daughters in $\geq 10$ herds in any participating country on the scale of each member country's national evaluation (country

Received December 21, 2006.

Accepted March 7, 2008.

${ }^{1}$ Corresponding author: rex.powell@ars.usda.gov

${ }^{2}$ Current address: Department of Animal Sciences, University of Florida, PO Box 110910, Gainesville 32611-0910. scale). International comparisons are possible because some bulls have daughters in multiple countries. Even though about $95 \%$ of Holstein bulls with evaluations in the Interbull database have daughters in only one country, pedigree connections also contribute to making evaluations comparable for all bulls. Country data are tied together through the use of common bulls, full and paternal brothers, and three-quarters brothers. Pedigree ties and evaluations of multicountry bulls and families determine the correlations between country scales included in the multiple across-country evaluation (MACE) procedure (Schaeffer, 1994) used by Interbull. Estimates of genetic correlations between countries are $<1$; thus, ranking of bulls differs across countries to a degree dependent on the genetic correlation between the countries. If national evaluations were biased, they could produce an unfair advantage for individual bulls or for all bulls from one country over another in international evaluations. Because a bull's true genetic merit is unknown, bias is difficult to discern and to quantify; therefore, use of information from full brothers seems a logical approach.

Full brothers sampled in different countries should have the same expected genetic merit, which would be reflected in their genetic means. The reliability of a group of bulls is much larger than the reliability for an individual member of the group, and the mean true merit is well estimated by the mean estimated merit. In both national and MACE evaluations, a bull's daughter information is regressed toward the parent average (PA). That regression is upward for some bulls and downward for others. The amount of that regression is dependent on the amount of effective daughter contribution, the primary factor that determines evaluation reliability (Fikse and Banos, 2001). Bulls with greater reliability generally have EBV that deviate further from PA.

Comparisons of MACE evaluations within families may give an indication of whether biases exist for or against bulls from specific countries. Full brothers have been used to investigate evaluation techniques in previous studies. France used a full-brother approach for developing the intercept for conversion equations before 
the routine calculation of Interbull evaluations in 1995 (Mattalia and Bonaiti, 1993). Powell et al. (1997) applied a model that included full-brother family and country of bulls' daughters to Interbull evaluations on both the French and US scales. At the time, those 2 countries had the most full-brother families in common, and French full brothers had significantly greater evaluations for milk and protein yields on both countries' scales.

Preliminary research on evaluations from 1995 suggested that although country differences within fullbrother families existed with the official method, which used estimated genetic correlations less than unity, those differences were not evident when the same data were evaluated using genetic correlations of essentially 1.0 (Powell, 1999). Inclusion of the correlations improved prediction of later bull evaluations on other country scales only for the 2 countries with the lowest genetic correlations (Powell and Norman, 2000).

The objective of this study was to determine whether apparent country bias appears in Interbull evaluations reported on 10 different national scales by comparing the evaluations of full brothers. Comparisons within family indicate whether the international evaluation system (including input data) effectively and fairly converts an evaluation for a bull in a foreign country to be comparable with an evaluation for his domestic full brother.

\section{MATERIALS AND METHODS}

\section{Data}

Data were May 2005 Interbull EBV for milk, fat, and protein yields and SCS for Holstein bulls. Information about Interbull evaluations (e.g., methods, sire standard deviations, and estimated genetic correlations) is available at the Interbull Web site (Interbull, 2005). Interbull processes evaluations from bulls that have been tested through an AI program, have daughters in $\geq 10$ herds in a national evaluation, and have birth dates of 1986 or later (for Holsteins). To avoid ambiguity in defining home country, bulls with daughters in $>1$ country were excluded $(<10 \%$ of bulls from full-brother families). Although eliminating bulls with multicountry daughter data was not desirable, those bulls could not be assigned to a single country as source of the data. They did still provide connectional information through their inclusion in the Interbull evaluations that were used as data for the study. Home country was designated as the country of daughters that contributed to the Interbull evaluation, which may not have been the bull's country of birth. Interest was in bias depending on where daughter data occur, not where the bull originated.
Bulls were required to have $\geq 1$ full brother with a usable evaluation. The estimation of country differences within full-brother families required that bulls be in multicountry families, but data from bulls in singlecountry families were also included in the analysis to improve estimates of within-country variation. A final edit required that each bull's home country be represented in $\geq 25$ multicountry families. Those requirements resulted in evaluations from 18 countries for yield and 15 countries for SCS; the 3 countries that were not included in the SCS analysis were not providing SCS data to Interbull in May 2005. The populations eliminated for yield or SCS included $<2 \%$ of the bulls in multicountry families and $<2 \%$ of the family ties between countries and did not affect the common families for remaining countries. Yield evaluations were expressed in kilograms of EBV for all countries by converting units of expression when necessary. Some national evaluation systems express SCS evaluations with larger numbers as desirable and others with smaller numbers as desirable. To facilitate the interpretation of results, signs on evaluations were reversed for France, Japan, the Netherlands, Spain, and Sweden so that smaller SCS numbers were desirable for all countries.

No age range within families was imposed, but the maximum observed was 5 calendar years for 1 family. Thus, no effect on data was expected because of full brothers that resulted from breedings based on a progeny test of a bull in a different country. Second and subsequent full brothers existed before the first brother received its progeny test. Daughters of the later bulls could have received preferential treatment; for example, if the first brother's progeny test was particularly favorable. However, $65 \%$ of the families included only bulls born in the same year, and another $30 \%$ of families had differences of only 1 calendar year. Therefore, brothers generally were sampled and their daughters milked at about the same time.

Although marker-assisted selection would permit progeny testing of only the more promising siblings, it was disregarded as a cause for country differences because it would not have been used extensively, if at all, during the period covered by this study. Bull birth dates ranged from 1986 to 2000 . Fewer than $10 \%$ of the bulls were born after 1998; nearly half were born before 1994 .

\section{Methods}

The model for evaluations included fixed effects for full-brother family and home country. Analysis was by PROC GLM of SAS (SAS Institute, 2005). Evaluations were weighted by the reliability of the Interbull evaluation. Solutions for home country effects were calculated 
Table 1. Numbers of single-country, multicountry, and all fullbrother families with May 2005 International Bull Evaluation Service evaluations ${ }^{1}$ for yield or SCS for all included brothers and numbers of bulls in those families

\begin{tabular}{llrrc}
\hline Trait & Family type & $\begin{array}{c}\text { Families } \\
(\mathrm{n})\end{array}$ & $\begin{array}{c}\text { Bulls } \\
(\mathrm{n})\end{array}$ & $\begin{array}{c}\text { Bulls per } \\
\text { family (n) }\end{array}$ \\
\hline Yield & Single country & 6,548 & 14,691 & 2.24 \\
& Multicountry & 3,600 & 9,920 & 2.76 \\
& All & 10,148 & 24,611 & 2.43 \\
SCS & Single country & 6,164 & 13,778 & 2.24 \\
& Multicountry & 3,284 & 9,024 & 2.75 \\
& All & 9,448 & 22,802 & 2.41 \\
\hline
\end{tabular}

${ }^{1}$ Evaluations were for bulls with daughters in countries represented in $\geq 25$ families.

relative to the United States. Evaluations of US EBV were the primary interest of this study, but the analysis was also repeated with evaluations on several other countries' scales. Significance testing for country solutions was relative to the United States.

\section{RESULTS AND DISCUSSION}

Numbers of families and bulls in single-country and multicountry families are in Table 1 . The typical fullbrother family had 2 members. Approximately $65 \%$ of families were single-country families, but mean family size (minimum of 2) was greater for multicountry families (2.8) than for single-country families (2.2). Including single-country families reduced standard errors of contrasts between evaluations for US bulls and those from other countries by approximately $2 \%$ for all traits, increasing the power for significance testing.

For multicountry families, Table 2 presents the numbers of families represented and numbers of bulls by home country. Most multicountry families had only 1 member per home country and included bulls from only 2 countries. The largest multicountry family consisted of 9 bulls in 5 countries. The United States was the most common home country ( $22 \%$ of all bulls in multicountry families), and almost half (45\%) of multicountry families had at least 1 US bull. France and Germany had 17 and $12 \%$ of the bulls, with representatives in 32 and $26 \%$ of the multicountry families, respectively. Only $4 \%$ of the bulls in multicountry families were from the combination of Australia, Hungary, New Zealand, Poland, South Africa, and Sweden. The largest number of countries for a family was 6 ; that family included 7 bulls.

Numbers of ties among countries (i.e., common families) are in Table 3 for yield and SCS. Numbers and distribution of ties were affected by the population sizes and similarity of breeding goals. Success of marketing efforts also affected number of ties for a country. For yield, the greatest number of ties was between the
Table 2. Numbers ${ }^{1}$ of multicountry full-brother families with May 2005 International Bull Evaluation Service evaluations for yield or SCS and numbers of bulls in those families by country of bull daughters (home country)

\begin{tabular}{lccccc}
\hline & \multicolumn{2}{c}{ Yield } & & \multicolumn{2}{c}{ SCS } \\
\cline { 2 - 3 } \cline { 5 - 6 } Home country & $\begin{array}{c}\text { Families } \\
\text { (n) }\end{array}$ & $\begin{array}{c}\text { Bulls } \\
\text { (n) }\end{array}$ & & $\begin{array}{c}\text { Families } \\
(\mathrm{n})\end{array}$ & $\begin{array}{c}\text { Bulls } \\
(\mathrm{n})\end{array}$ \\
\hline Australia & 86 & 104 & & 55 & 63 \\
Canada & 641 & 750 & & 628 & 733 \\
Czech Republic & 122 & 128 & & - & - \\
Denmark & 505 & 641 & & 486 & 613 \\
France & 1,163 & 1,685 & & 1,090 & 1,585 \\
Germany & 940 & 1,206 & & 845 & 1,072 \\
Great Britain & 468 & 549 & & 432 & 510 \\
Hungary & 67 & 76 & & 54 & 60 \\
Ireland & 159 & 169 & & - \\
Italy & 237 & 294 & & 223 & 274 \\
Japan & 763 & 871 & & 754 & 862 \\
Netherlands & 637 & 819 & & 599 & 773 \\
New Zealand & 44 & 53 & & 39 & 47 \\
Poland & 70 & 77 & & - & - \\
South Africa & 32 & 36 & & 30 & 34 \\
Spain & 215 & 253 & & 207 & 245 \\
Sweden & 48 & 58 & & 44 & 53 \\
United States & 1,631 & 2,151 & 1,596 & 2,100 \\
\hline
\end{tabular}

${ }^{1}$ Evaluations were for bulls with daughters in countries represented in $\geq 25$ families.

United States and Japan (491); $>50 \%$ of ties for Japan and $>25 \%$ of ties for the United States. Canada had $43 \%$ of full-brother ties via the United States. In contrast, Denmark had $46 \%$ of its ties via Germany and only $9 \%$ through the United States. With $<50$ families, Sweden had no direct ties to 9 countries, and $65 \%$ of their ties were with Denmark, although that provided only 5\% of the ties for Denmark. Distributions were similar for countries with SCS.

The overall ANOVA for home country effect indicated differences $(P<0.0001)$ in US EBV for all traits. Solutions for individual home country effects on US EBV are in Table 4. Relative to US bulls, full brothers from other home countries were generally at an advantage for milk yield, significantly $(P<0.05)$ so for Australia, France, Germany, Great Britain, Japan, and Spain. In contrast, bulls from Italy were at a disadvantage $(P<$ $0.05)$ relative to US bulls and, thus, even more so relative to bulls from most other countries. Swedish bulls had the largest unfavorable EBV difference for milk, although that difference was not significant $(P=0.15)$.

For fat yield, significant $(P<0.05)$ EBV differences relative to US bulls were not as frequent. Australian, British, and South African bulls again had an advantage. Results for protein yield were similar to those for milk yield. Bulls from Australia, Germany, Great Britain, Japan, and South Africa were at an advantage $(P<0.05)$ relative to US bulls. Solutions for SCS were near zero except for South African bulls, which were disadvantaged relative to US bulls $(P<0.01)$. 
Table 3. Numbers of full-brother families in common (ties) between countries based on May 2005 International Bull Evaluation Service evaluations ${ }^{1}$ for yield (above diagonal) and SCS (below diagonal) by country of bull daughters (home country)

\begin{tabular}{|c|c|c|c|c|c|c|c|c|c|c|c|c|c|c|c|c|c|c|}
\hline Home country & AUS & CAN & $\mathrm{CZE}$ & DNK & FRA & $\mathrm{DEU}$ & GBR & HUN & IRL & ITA & JPN & NLD & NZL & POL & $\mathrm{ZAF}$ & ESP & SWE & USA \\
\hline Australia (AUS) & & 10 & 1 & 4 & 18 & 3 & 6 & 0 & 2 & 3 & 11 & 17 & 12 & 0 & 2 & 2 & 0 & 32 \\
\hline Canada (CAN) & 5 & & 3 & 18 & 88 & 67 & 36 & 8 & 1 & 13 & 111 & 14 & 3 & 0 & 5 & $5 \overline{9}$ & 0 & 337 \\
\hline Czech Republic (CZE) & $-^{2}$ & - & & 9 & 16 & 63 & 5 & 10 & 0 & 3 & 4 & 19 & 0 & 6 & 1 & 3 & 0 & 11 \\
\hline France (FRA) & 11 & 85 & - & 62 & & 156 & 145 & 0 & 40 & 81 & 151 & 152 & 6 & 35 & 10 & 44 & 1 & 476 \\
\hline Germany (DEU) & 3 & 66 & - & 295 & 155 & & 67 & 29 & 46 & 40 & 47 & 145 & 5 & 22 & 6 & 36 & 6 & 140 \\
\hline Great Britain (GBR) & 5 & 35 & - & 31 & 138 & 65 & & 0 & 36 & 33 & 49 & 107 & 4 & 2 & 3 & 15 & 0 & 109 \\
\hline Hungary (HUN) & 0 & 8 & - & 3 & 0 & 28 & 0 & & 0 & 1 & 3 & 5 & 0 & 1 & 0 & 3 & 1 & 18 \\
\hline Japan (JPN) & 5 & 111 & - & 26 & 150 & 47 & 49 & 2 & - & 13 & & 25 & 2 & 0 & 6 & 33 & 0 & 491 \\
\hline The Netherlands & & & & & & & & & & & & & & & & & & \\
\hline $\begin{array}{l}\text { (NLD) } \\
\text { New } 7 \text { and (NZI) }\end{array}$ & 16 & 14 & - & 48 & 152 & 145 & 102 & 5 & - & 48 & 25 & & 4 & 0 & 2 & 15 & 8 & 154 \\
\hline New Zealand (NZL) & 7 & 3 & - & 1 & 6 & 5 & 4 & 0 & - & 0 & 2 & 4 & & 0 & 0 & 1 & 0 & 15 \\
\hline Poland (POL) & - & - & - & - & - & - & — & — & - & - & — & - & - & & 0 & 3 & 1 & 6 \\
\hline South Africa (ZAF) & 1 & 5 & - & 1 & 8 & 6 & 3 & 0 & - & 1 & 6 & 2 & 0 & - & & 2 & 0 & 8 \\
\hline
\end{tabular}

${ }^{1}$ Evaluations were for bulls with daughters in countries represented in $\geq 25$ families.

${ }^{2}$ SCS not evaluated.

Although marker-assisted selection was discounted as a factor in selection of the most promising bulls to progeny test, other selection practices within fullbrother "litters" produced by multiple ovulation and embryo transfer could result in country differences in

Table 4. Estimated differences in US EBV between foreign and US full brothers for May 2005 International Bull Evaluation Service evaluations for yield and $\operatorname{SCS}^{1}$ by country of bull daughters (home country)

\begin{tabular}{lcccc}
\hline & \multicolumn{4}{c}{ EBV difference (foreign - US) } \\
\cline { 2 - 5 } Home country & Milk (kg) & Fat $(\mathrm{kg})$ & Protein $(\mathrm{kg})$ & $\mathrm{SCS}^{2}$ \\
\hline Australia & $137^{*}$ & $5.4^{*}$ & $3.1^{*}$ & 0.03 \\
Canada & 12 & -1.2 & -0.3 & 0.00 \\
Czech Republic & 71 & 0.2 & 0.6 & $-{ }^{3}$ \\
Denmark & 38 & -1.5 & 0.5 & 0.02 \\
France & $51^{* *}$ & 0.2 & 0.8 & 0.01 \\
Germany & $95^{* * *}$ & 0.7 & $1.9^{* * *}$ & 0.02 \\
Great Britain & $109 * *$ & $1.9 *$ & $2.0^{* *}$ & 0.02 \\
Hungary & 6 & 0.0 & 0.1 & 0.03 \\
Ireland & 16 & -0.9 & -0.3 & - \\
Italy & $-70^{*}$ & 0.0 & -1.3 & 0.00 \\
Japan & $87^{* * *}$ & 0.0 & $1.8^{* * *}$ & 0.01 \\
Netherlands & -7 & -0.3 & -1.0 & 0.00 \\
New Zealand & 13 & 2.7 & -1.0 & -0.01 \\
Poland & 43 & -2.6 & 0.2 & - \\
South Africa & 114 & $7.9 *$ & $6.6^{* *}$ & $0.17 * *$ \\
Spain & $84^{*}$ & 0.4 & 1.1 & -0.01 \\
Sweden & -104 & -4.6 & -1.5 & 0.05 \\
\hline
\end{tabular}

${ }^{1}$ PROC GLM solutions with US solution set to 0 .

${ }^{2} \mathrm{SCS}$ in United States reported as log base $2(\mathrm{SCC} / 100,000)+3$.

${ }^{3} \mathrm{SCS}$ not evaluated.

$* P<0.05 ; * * P<0.01 ; * * * P<0.001$ estimated genetic merit. Characteristics of candidate bulls could determine which bull is progeny tested. However, those characteristics likely would be traits related to fitness of the bull calf as a future semen producer (e.g., health or vigor) with little relation to the traits examined in this study (yield and SCS). Because more bulls have US parents than parents from other countries, the greatest opportunity for selection of candidate bulls would be expected to be in the United States. However, the US bulls appear to be disadvantaged, which does not support a positive impact by any such selection and indicates that it likely is not a factor that contributes to country differences in bull merit.

Bull EBV had been weighted by its associated Interbull reliability for the analysis reported in Table 4 . That weighting seemed reasonable, as the various bull EBV provided different amounts of information and confidence as reflected in the reliability. Although the reported results are from the weighted analysis, the analysis was also conducted without weighting. Results changed little from those in Table 4. Only one significance level changed (from 0.0110 to 0.0087 ). Maximum changes from country solutions in Table 4 were $5 \mathrm{~kg}$ for milk yield, $0.04 \mathrm{~kg}$ for fat yield, and $0.04 \mathrm{~kg}$ for protein yield. For SCS, 2 numbers changed by 0.01 , with the rest the same as reported for the weighted analysis. Thus, weighting had minimal impact.

Because US export marketing can be affected by bias among evaluations, differences among evaluations on country scales other than the United States were also 
Table 5. Significance ${ }^{1}$ of differences in EBV of non-US bulls compared with their US full brothers on the evaluation scales of various countries by home country ${ }^{2}$ of non-US bulls ${ }^{3}$

\begin{tabular}{|c|c|c|c|c|c|c|c|c|c|c|c|}
\hline \multirow[b]{2}{*}{ Home country } & \multirow[b]{2}{*}{ Trait } & \multicolumn{10}{|c|}{ Country of evaluation scale ${ }^{4}$} \\
\hline & & AUS & CAN & FRA & DEU & GBR & ITA & JPN & NLD & NZL & USA \\
\hline \multirow[t]{3}{*}{ Australia (AUS) } & Milk & ++ & + & + & + & ++ & + & + & + & ++ & + \\
\hline & Fat & +++ & ++ & ++ & + & ++ & ++ & ++ & + & ++ & + \\
\hline & Protein & ++ & + & + & NS & + & NS & + & NS & ++ & + \\
\hline Denmark & Fat & - & NS & NS & NS & - & NS & NS & NS & NS & NS \\
\hline France (FRA) & Milk & & + & + & + & + & + & + & + & + & ++ \\
\hline \multirow[t]{2}{*}{ Germany (DEU) } & Milk & +++ & +++ & +++ & +++ & +++ & +++ & +++ & +++ & +++ & +++ \\
\hline & Protein & ++ & ++ & ++ & ++ & ++ & ++ & ++ & ++ & ++ & +++ \\
\hline \multirow[t]{3}{*}{ Great Britain (GBR) } & Milk & +++ & +++ & +++ & +++ & +++ & +++ & +++ & +++ & +++ & +++ \\
\hline & Fat & + & + & + & & + & + & + & + & + & + \\
\hline & Protein & ++ & ++ & ++ & + & ++ & ++ & ++ & ++ & ++ & ++ \\
\hline \multirow[t]{2}{*}{ Italy (ITA) } & Milk & - & - & - & - & - & -- & - & - & - & - \\
\hline & Protein & NS & NS & NS & NS & NS & - & NS & NS & NS & NS \\
\hline \multirow[t]{2}{*}{ Japan (JPN) } & Milk & +++ & +++ & +++ & +++ & +++ & +++ & +++ & +++ & +++ & +++ \\
\hline & Protein & +++ & +++ & +++ & +++ & +++ & +++ & +++ & +++ & +++ & +++ \\
\hline Netherlands (NLD) & Protein & - & - & - & - & - & - & - & -- & - & NS \\
\hline \multirow[t]{3}{*}{ South Africa } & Fat & + & + & + & + & + & + & + & + & + & + \\
\hline & Protein & + & ++ & ++ & ++ & ++ & ++ & ++ & ++ & + & ++ \\
\hline & SCS & ++ & ++ & ++ & ++ & ++ & ++ & ++ & ++ & ++ & ++ \\
\hline Spain & Milk & + & + & + & NS & + & + & + & + & + & + \\
\hline Sweden & Fat & NS & NS & NS & NS & - & NS & NS & NS & NS & NS \\
\hline
\end{tabular}

${ }^{1}$ Significance of differences in full-brother EBV that favor a non-US home country are indicated by $+(P$ $<0.05),++(P<0.01)$, or $+++(P<0.001)$; differences that favor the United States (USA) are indicated by $-(P<0.05)$ or $--(P<0.01)$. Traits without significant differences from US bulls are indicated by NS.

${ }^{2}$ Country of daughters that contributed to Interbull evaluations.

${ }^{3}$ Brothers from Canada (CAN), Czech Republic, Hungary, Ireland, New Zealand (NZL), and Poland did not differ significantly from US brothers for any traits on any evaluation scales.

${ }^{4}$ National scale on which Interbull evaluations were expressed.

of interest. Were observed discrepancies evident across country scales, or were Italy and the United States generally disadvantaged for milk yield only on the US scale as shown in Table 4? Table 5 indicates the differences $(P<0.05)$ from US solutions for yield traits on 10 country scales. Those countries were the 8 with the most data, plus Australia and New Zealand because they have lower genetic correlations with most other countries. For ease of comparison, information on significance on the US scale is repeated. Traits within country were not included if all differences with other countries were nonsignificant $(P \geq 0.05)$. Home country continued to be the country of daughters that contributed to the Interbull evaluation. Country scale was the national scale on which Interbull evaluations were expressed. The key finding is that the situation is nearly identical across country scales. For milk, Australian, French, German, British, Japanese, and Spanish full brothers had greater $(P<0.05)$ family solutions relative to US full brothers on nearly all country scales and usually with the same significance level. Italian bulls had smaller EBV $(P<0.05)$ on all country scales.

Many fewer differences $(P<0.05)$ were found for fat yield, but the differences again were consistent across country scales: Australian, British, and South African bulls had an advantage. Results for protein yield were similar to those for milk yield. Australian, German, British, Japanese, and South African bulls had an advantage $(P<0.05)$ relative to US bulls, whereas Dutch bulls were disadvantaged $(P<0.05)$. For SCS, only solutions for South African bulls differed $(P<0.01)$ from US bulls (greater) on all country scales.

Mean differences from US bulls (solutions in Table 4) were weighted by number of bulls per home country (Table 2) and are reported in Table 6 for yield traits on the US scale of evaluation and similarly for other country scales of evaluation. Mean EBV difference on the US scale was $50 \mathrm{~kg}$ of milk, favoring foreign bulls over US full brothers. Mean differences from the United States are not as much of a concern as differences for individual countries, and mean EBV differences between foreign and domestic brothers for 9 other countries also are in Table 6. Because SCS differences were significant $(P<0.01)$ only for one country, they were not included in Table 6 . A bull was considered to be "domestic" if country of evaluation scale and home country were the same and to be "foreign" if country of evaluation scale and home country differed. Positive numbers indicated that brothers from other countries had larger EBV than their domestic full brothers; thus, foreign bulls were advantaged. Conversely, negative numbers implied that foreign bulls were disadvan- 
Table 6. Advantages in EBV of foreign ${ }^{1}$ compared with domestic ${ }^{2}$ bulls weighted by number of bulls per foreign home country (Table 2)

\begin{tabular}{lccc}
\hline \multirow{2}{*}{$\begin{array}{l}\text { Country of } \\
\text { evaluation }\end{array}$} & \multicolumn{3}{c}{ Mean EBV difference (foreign - domestic) } \\
\cline { 2 - 4 } & Milk $(\mathrm{kg})$ & Fat $(\mathrm{kg})$ & Protein $(\mathrm{kg})$ \\
\hline Australia & -66 & -4.0 & -1.6 \\
Canada & 39 & 1.8 & 1.4 \\
France & -6 & 0.0 & 0.1 \\
Germany & -48 & -0.6 & -1.2 \\
Great Britain & -58 & -1.7 & -1.3 \\
Italy & 129 & 0.4 & 2.9 \\
Japan & -55 & -0.1 & -1.4 \\
Netherlands & 62 & 0.5 & 2.0 \\
New Zealand & 22 & -1.4 & 1.1 \\
United States & 50 & 0.1 & 0.8 \\
\hline
\end{tabular}

${ }^{1}$ Country of daughters (home country) different from country of the evaluation scale (national scale on which Interbull evaluations were expressed).

${ }^{2}$ Country of daughters (home country) the same as country of the evaluation scale (national scale on which Interbull evaluations were expressed).

taged. Generally, the differences were within a fairly narrow range, which would indicate that genetic progress might not be seriously affected from such differences. If importations are from several countries, effect of any bias for a particular country would be diminished. However, the ranges of differences on each country scale show that marketers from specific countries might be importantly advantaged or disadvantaged relative to another country. The estimated within-family difference for US evaluations had a range of $241 \mathrm{~kg}$ for EBV for milk yield across bulls' home countries (Table 4). The range was less (106 to $171 \mathrm{~kg}$ for EBV for milk yield, not shown) for countries with less evaluation variation (Australia, Great Britain, and New Zealand). Differences for other countries ranged from 212 to $276 \mathrm{~kg}$ (not shown), which was similar to that in the United States.

Table 7 presents the rankings of the home-country solutions for EBV for protein yield on the evaluation scales of several countries. Those solutions are the differences for full brothers in the various countries, not the merit of the bulls themselves. However, in theoretical families with a brother from each country, expected genetic merit is the same (i.e., on average, equal ranking of all bulls and ranking within any family are due to Mendelian sampling); this study indicates that the particular rank of brothers would result partly from their home country. The rankings are similar across countries of evaluation; that is, if bulls within a family and from a given country had greater evaluations in one country, they tended to have greater evaluations on all country evaluations. Full brothers from South Africa had the largest evaluations on all country scales; brothers from Sweden had the lowest evaluations, with brothers from Italy usually the next lowest. The maximum rank difference was 2 positions across country scales; 5 countries ranked the same on all country scales, 7 differed by 1 position, and 6 differed by 2 positions.

Based on percentages of bulls with dams and daughters from the same country (Table 7), countries using local dams (i.e., exporting countries) clearly tended to be those disadvantaged. This finding is in agreement with Sullivan et al. (2005), who studied simulated exporting and importing populations, and reported that biases favored bulls from importing countries.

Van Doormaal et al. (1999) estimated the ratios of sire standard deviation estimates shown in Table 7 by using birth date windows for national sire evaluations for the most recent $5 \mathrm{yr}$ vs. $12 \mathrm{yr}$ (all available years). If sire standard deviations for a country are more correctly represented by younger bulls, then larger estimates from the longer period used by Interbull would penalize all bulls from that country on all country scales. Conversely, countries with the larger ratios are advantaged, as shown in Table 7 where the ratios correspond closely with apparent bias.

Although the use of genetic correlations of $<1.0$ could have caused an advantage for bulls evaluated on the evaluation scale of their home country, differences were not related to country of evaluation; results (ranking of country solutions) were essentially the same for all country scales. The impact of using genetic correlations of essentially unity was not available for examination in this study.

Historically, in many situations of apparent bias, preferential treatment has been implicated, justifiably or not. Bulls in this study were not subsequently used in a second country where they might have received differential treatment; they were evaluated in only 1 country and, therefore, were essentially local bulls (i.e., not selected because of a favorable progeny test in another country). However, their sires or other male relatives may have been used in $>1$ country with the possibility of preferential treatment, thus causing bias of PA. Mean reliability for all bulls was $74 \%$ on the US scale, a reasonable level considering that bulls with daughters in other countries were not included (they would generally have had greater reliabilities) and most bulls were from other countries (genetic correlations would diminish reliabilities).

Brothers from some countries appear advantaged or disadvantaged and that advantage or disadvantage likely applies to other bulls from those countries. However, recent studies have suggested that the evaluations converted across countries though MACE are effective. McClintock et al. (2003) found that Interbull evaluations for imported bulls were relatively unbiased 
Table 7. Rankings of home countries ${ }^{1}$ for solutions (apparent bias) for full-brother EBV for protein yield on the evaluation scales of various countries, ${ }^{2}$ percentages of home-country bulls with a dam from the same country, and sire SD ratios

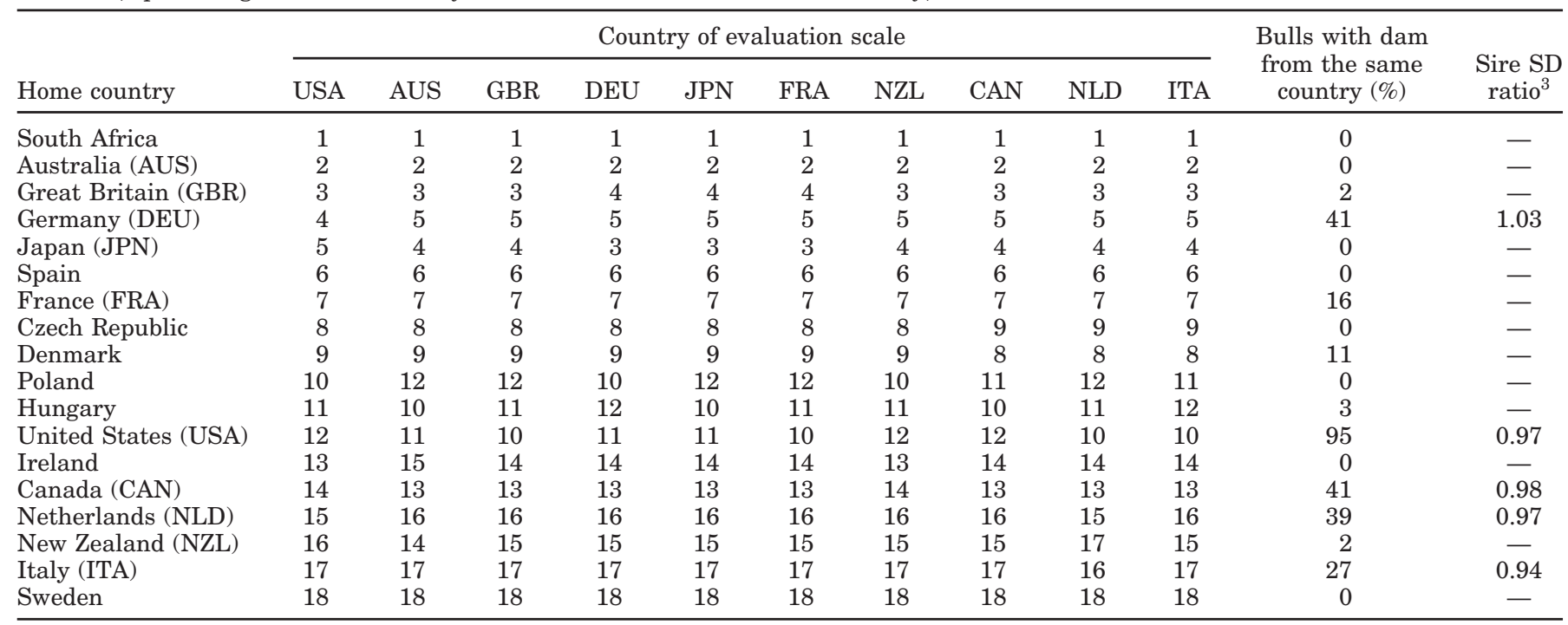

${ }^{1}$ Country of daughters that contributed to Interbull evaluations.

${ }^{2}$ National scale on which Interbull evaluations were expressed.

${ }^{3}$ Estimated by Van Doormaal et al. (1999) as the ratio of sire SD for bulls born from 1989 through 1993 to sire SD for bulls born from 1982 through 1993.

predictors of later Australian evaluations. Powell et al. (2004) reported that Interbull estimates were good predictors of later national evaluations in the United States. Differences averaged near zero, and correlations of evaluations were essentially as expected from estimates of Interbull and US reliability. Brochard et al. (2006) stated that Interbull genetic evaluations for foreign bulls were not only accurate predictors of later French evaluations but more so than expected from reliabilities. Even if bulls from certain countries were biased, the amount of bias may have been small enough (especially when averaged with all bulls with imported semen from all countries) that the impact was not appreciable. However, substantial financial consequences in international marketing may result for some individual pairs of countries.

Reasons for full brothers from one country being advantaged or disadvantaged in another country were not determined in this study. If domestic bulls are advantaged or disadvantaged in their own national evaluation, then that inequity could be carried through the MACE system to appear similarly on other country scales. Several differences in evaluation systems could have a role: single vs. multitrait model, test-day vs. lactation model, interaction between genotype and environment, and procedures for considering parental information.

Several recent reports have suggested the need for improving PA contribution to both national and MACE evaluations. Mrode and Swanson (1999) stressed that
PA information in the importing country can have a large effect and may be biased by preferential treatment of male ancestors. No standard procedure exists for incorporating PA for foreign animals in national evaluations. Some countries may make use of foreign information for sires and dams, whereas other countries may use only data from their own system or unknownparent group solutions. Klei and Lawlor (2003) cited the acute problem with inaccurate PA from limited information in estimates for phantom maternal granddam (MGD) and suggested a postevaluation adjustment with converted PA information.

Mark and Sullivan (2006) suggested that errors in estimated daughter performance from the deregression process at the Interbull Centre (Uppsala, Sweden) result if different pedigree data are used than those used in the national evaluation. The Centre uses the most complete pedigree data, and some countries' national data may not be complete and may even disagree. Thus, deregression may consider information not used at the national level with the result that the estimated daughter performance is in error. That error may lead to more disagreement between national and Interbull evaluations than necessary; as a result, bulls from certain countries conceivably could be generally ranked higher or lower than appropriate.

At the Interbull Centre, only male pedigree data are used (i.e., sire and maternal grandsire), and the remaining quarter of PA comes from estimates for MGD groups by MGD country and year of bull birth (De Jong, 
2003). If the Interbull PA is different from that used in the national evaluation, then the difference in the Interbull estimate for Mendelian sampling for the bull will be of equal size but in the opposite direction from that in the evaluating country. On another country's scale, the full discrepancy in Mendelian sampling estimate will be converted but only a portion of the opposing discrepancy in PA, because local data for sire and maternal grandsire reduce the need for conversion of those data.

Van der Linde et al. (2005) reported that differences in evaluations between MACE with pedigree data for sire and maternal grandsire and MACE with full (animal) pedigree data were small but slightly favored the latter. Female records were included, but only for pedigree entries and not for performance. Evaluations of bull dams often have been found to be positively biased, and inclusion of such data is not necessarily beneficial. The procedure for full pedigree was tested at the Interbull Centre with data submitted for March 2007 test evaluations but was demanding of computing time and memory; implementation is pending the adoption of more efficient computing algorithms (F. Fikse, Interbull Centre, Uppsala, Sweden; personal communication).

\section{CONCLUSIONS}

Solutions for country of evaluation suggest possible bias for or against bulls from some countries. The most significant differences were for milk yield followed by protein yield and then fat yield, with little apparent bias for SCS. However, this investigation did not reveal the source of the differences. Varying practices for including PA data in national evaluations and use of phantom group solutions to proxy for MGD in Interbull evaluations may contribute to the problem documented here. The possible use of full pedigree data in MACE could be beneficial. Although any bias is undesirable, genetic progress may not have been seriously affected. The resolution to apparent biases likely will be in the improvement of both data (including making full use of data) and evaluation procedures.

\section{ACKNOWLEDGMENTS}

The willingness of the genetic evaluation centers in all countries to permit examination of evaluations on their national scales was necessary for this research and is gratefully acknowledged. The assistance of J. R. Wright, Animal Improvement Programs Laboratory, ARS, USDA (Beltsville, MD), in computing is appreciated. Comments from the reviewers were extremely beneficial.

\section{REFERENCES}

Brochard, M., S. Minéry, and S. Mattalia. 2006. Accuracy of international evaluations in predicting French estimated breeding values of foreign Holstein bulls. Interbull Bull. 35:67-71.

De Jong, G. 2003. MACE-Options for improvement. Interbull Bull. $30: 112-116$

Fikse, W. F., and G. Banos. 2001. Weighting factors of sire daughter information in international genetic evaluations. J. Dairy Sci. 84:1759-1767.

Interbull. 2005. Interbull routine genetic evaluation for dairy production traits, November 2005. http://www-interbull.slu.se/eval/ nov05.html. Accessed Jan. 3, 2008.

Klei, B., and T. Lawlor. 2003. Advantages of using multiple country converted parent averages in Mace. Interbull Bull. 30:117-125.

Mark, T., and P. G. Sullivan. 2006. Multiple-trait multiple-country genetic evaluations for udder health traits. J. Dairy Sci. 89:4874-4885.

Mattalia, S., and B. Bonaiti. 1993. Use of full sib families to estimate the 'a' coefficients of conversion formulas between countries. Interbull Bull. 8:73-74.

McClintock, S., K. Beard, and R. Poole. 2003. Interbull proofs are a reasonably unbiased prediction of future performance in Australia for imported bulls. Interbull Bull. 31:169-170.

Mrode, R. A., and G. J. T. Swanson. 1999. Simplified equations for evaluations of bulls in the Interbull international evaluation system. Livest. Prod. Sci. 61:43-52.

Powell, R. L. 1999. Investigation of country bias in international genetic evaluations through full brothers. J. Dairy Sci. 82(Suppl. 1):73. (Abstr.)

Powell, R. L., and H. D. Norman. 2000. Impact of genetic correlations on accuracy of predicting future evaluations. J. Dairy Sci. 83:1552. (Online; available: http://jds.fass.org/).

Powell, R. L., A. H. Sanders, and H. D. Norman. 2004. Accuracy of foreign dairy bull evaluations in predicting United States evaluations for yield. J. Dairy Sci. 87:2621-2626.

Powell, R. L., G. R. Wiggans, and M. Sieber. 1997. Consistency of international genetic evaluations of Holstein bulls. J. Dairy Sci. 88:2177-2183.

SAS Institute. 2005. SAS OnlineDoc 9.1.3. http://support.sas.com/ onlinedoc/913/docMainpage.jsp. SAS Inst. Inc., Cary, NC. Accessed Jan. 3, 2008.

Schaeffer, L. R. 1994. Multiple-country comparison of dairy sires. J. Dairy Sci. 77:2671-2678.

Sullivan, P. G., J. W. Wilton, L. R. Schaeffer, G. J. Jansen, J. A. B. Robinson, and O. B. Allen. 2005. Genetic evaluation strategies for multiple traits and countries. Livest. Prod. Sci. 92:195-205.

Van der Linde, C., A. P. W. de Roos, A. G. F. Harbers, and G. de Jong. 2005. MACE with sire-mgs and animal pedigree. Interbull Bull. 33:3-7.

Van Doormaal, B. J., G. J. Kistemaker, and P. G. Sullivan. 1999. Heterogeneous variances of Canadian bull EBVs over time. Interbull Bull. 22:141-148. 